\title{
RESPONSES OF HEMATOLOGY, BLOOD METABOLITES, MINERAL IONS AND HORMONAL PROFILE TO HEAT STRESS FOR EGYPTIAN BUFFALO-CALVES
}

\author{
OMRAN, FAYZA I. ${ }^{1}$, G. ASHOUR ${ }^{2}$, M. M. YOUSSEF ${ }^{1}$ AND M. M. SHAFIE ${ }^{2}$ \\ 1 Animal Production Research Institute, ARC, Ministry of Agriculture, Dokki, Giza \\ 2 Faculty of Agriculture, Cairo University
}

(Manuscript received 7 February 2011)

\begin{abstract}
This study was carried out at the Experimental Farm of the Animal Physiology Research Lab, Faculty of Agriculture, Cairo University, during the summer season of 2004. The objective was to assess the relevant physiological responses and growth performance of Egyptian buffalo-calves to artificial constant severe heat stress. Eight buffalo-calves were randomly divided into lab $\mathrm{A}$ and lab B, their age and live body weight were 6 months and about $119 \mathrm{~kg}$, respectively. All calves were assessed under two constant thermal conditions, heat stress $\left(40{ }^{\circ} \mathrm{C}\right.$ and $87.5 \% \mathrm{RH}$, lab A) and comfort state $\left(25{ }^{\circ} \mathrm{C}\right.$ and $64.5 \% \mathrm{RH}$, lab B). Two trials were conducted, each one continued for one month in each lab. They were interrupted by 15 days under natural climatic outdoor conditions.

Values of $\mathrm{Ht}, \mathrm{Hb}$ and $\mathrm{RBCs}$ were reduced by heat stress during the two trials. The white blood cells count (WBCs) were significantly increased (around 50\%). Levels of total protein (TP), albumin (Alb), total lipids (TL), triglycerides (TG), total cholesterol (TC), glucose (Glu) and blood urea nitrogen (BUN) were decreased by heat stress during the two trials, while, the globulin (Glo) level was not affected. In the two trials, heat stress caused slight increase (4 to $8 \%$ ) in sodium $(\mathrm{Na})$ and potassium $(\mathrm{K})$, and increase (47 to $58 \%$ ) in phosphorus (P) level, and calcium (Ca) was decreased by $20 \%$. In both trials, heat stress decreased insulin (Ins), increased glycogen $(\mathrm{Glg})$ and both triiodothyronine $\left(\mathrm{T}_{3}\right)$ and thyroxine $\left(T_{4}\right)$ were dropped by about $50 \%$.

It can be concluded that buffalo-calves were able to maintain their lives with some chemical and physical changes that led to the delay in growth when exposed to high temperatures.
\end{abstract}

\section{INTRODUCTION}

Suitability of Egyptian buffaloes to hot climate is achieved by morphological, anatomical and physiological characteristics (Shafie, 1958, 1985, 1993 a, b, Ashour et al.,2000, 2004 and Omran, 1999, 2008). The tolerance capacity of Egyptian buffaloes was determined in Egypt under natural seasonal conditions and under artificial laboratory conditions of heat stress (Omran, 1999, 2008 and Ashour et. al., 2000 and 2004). 
The present work was carried out to identify the relevant physiological responses of Egyptian buffalo-calves under exposure to artificial heat stress $\left(40^{\circ} \mathrm{C}\right)$ and comfort $\left(25^{\circ} \mathrm{C}\right)$ as affecting changes in blood hematological picture, blood plasma metabolites, mineral and hormones.

\section{MATERIALS AND METHODS}

This study was carried out at the Experimental Farm of the Animal Physiology Research Lab, Animal Production Department, Faculty of Agriculture, Cairo University. The experimental procedures and data collection were executed during the summer season of 2004. The present work was executed to assess the relevant physiological responses of buffalo-calves to artificial constant severe heat stress. Eight buffalocalves (Bubalus bubalis) were available for this study from Mehalet Mousa Experimental Farm, Animal Production Research Institute, Agricultural Research Center, Ministry of Agriculture, Egypt. On the beginning of the experiment, the age of each calf was 6 months and its live body weight (BW) ranged between 118.0 - 119.3 $\mathrm{kg}$. All animals appeared healthy normally. They were divided into lab A and lab B.

This work was carried out under two constant thermal conditions (CTC), heat stress (HS) $40^{\circ} \mathrm{C}$, lab A and comfort state (CS) $25^{\circ} \mathrm{C}$, lab B. Two trials, each of which continued one month in both labs and were interrupted by 15 days under outdoors conditions.

Feeding a commercial concentrate ration was offered in surplus amount daily to determine the free - well fed intake (FI). The roughage feeds, wheat straw and Berseem (Trifolium alexandrinum) hay were also delivered in surplus. The concentrate ration consisted of a starter during the first month of experimentation (6-7 months), then, followed by a growth concentrate till the end of experimental work at the $9^{\text {th }}$ month.

Lab A was equipped by 4 heaters controlled by highly sensitive digital thermostat alongside ceiling and suction fans. Thus, the ambient temperature (AT) in this lab was fixed and maintained exactly at $40^{\circ} \mathrm{C}$, the relative humidity $(\mathrm{RH})$ was 87.3 $-87.7 \%$, and the temperature-humidity indexes (THI) were $101.2 \pm 0.1-100.0 \pm 0.1$ at the $1^{\text {st }}$ trial and $100.8 \pm 0.1-100.7 \pm 0.1$ at the $2^{\text {nd }}$ trial. Lab $B$ was equipped by air conditioner and ceiling fan to maintain the $\mathrm{AT}$ at $25^{\circ} \mathrm{C}$, the RH at $61.3-67.9 \%$ and the THI were $74.0 \pm 0.3-75.0 \pm 0.6$ at the $1^{\text {st }}$ trial and $75.8 \pm 0.5-76.7 \pm 0.2$ at the $2^{\text {nd }}$ trial. 
The blood sampling was carried out on the $1^{\text {st }}, 2^{\text {nd }}, 3^{\text {rd }}$ days, as well as on the $15^{\text {th }}$ day, and at the end of each period, the mean value expressed the data of the five measurements.

Blood samples were collected at 08:00h prior to morning feeding and watering in heparinzed tubes from the external Jugular vein. Directly, a portion of blood sample was used for determining hemoglobin ( $\mathrm{Hb}, \mathrm{g} / \mathrm{dl})$ conc., hematocrit value $(\mathrm{Ht}, \%)$, red blood cells count (RBCs, $\mathrm{X} 10^{6} / \mathrm{mm}^{3}$ ) and white blood cells count (WBCs, $\mathrm{X} 10^{3} / \mathrm{mm}^{3}$ ). Alongside, a blood smear was prepared for differential counts of leukocyte types. Another portion of blood sample was centrifuged for $30 \mathrm{~min}$ at 3000 rpm to collect clear plasma sample. The plasma samples were drawn into microcuvetts and stored at $-20^{\circ} \mathrm{C}$ until assaying the conc. of relevant, hormones, organic compounds and mineral ions.

The tested organic compounds were: total protein ( $T P, g / d l)$, albumin (Alb, $\mathrm{g} / \mathrm{dl})$, globulin (Glo, $\mathrm{g} / \mathrm{dl})$, total lipids $(\mathrm{TL}, \mathrm{mg} / \mathrm{dl})$, triglycerides $(\mathrm{TG}, \mathrm{mg} / \mathrm{dl})$, total cholesterol (TC, mg/dl), glucose (Glu, mg/dl) and blood urea nitrogen (BUN, mg/dl). The assessed minerals $(\mathrm{mg} / \mathrm{dl})$ were: sodium $(\mathrm{Na})$, potassium $(\mathrm{K})$, calcium $(\mathrm{Ca})$ and phosphorus $(P)$. The considered hormones were, triiodothyronine $\left(T_{3}\right)$, thyroxine $\left(T_{4}\right)$, insulin (Ins) and glucagon (Glg). Relevant statistical analysis of data was carried out applying the Statistical Analysis System (SAS, 2000).

\section{RESULTS AND DISCUSSION}

\section{Blood parameters}

\section{Hematological picture}

Table 1 shows that the values of $\mathrm{Ht}, \mathrm{Hb}$ and RBCs counts were significantly reduced $(-20 \%)$ by heat stress in the two trials. On the contrary, the WBCs count was significantly increased $(+50 \%)$ in response to this stress.

Several investigators reported that $(\mathrm{Hb}$ and $\mathrm{Ht}$ ) were decreased in heat stressed animals (Rowlands et. al., 1974, Bond et. al., 1984, Omran, 1999, 2008 and Ashour et. al., 2004). This reduction was attributed to the destruction of erythrocytes and / or to hemodilution (Shebaita and Kamal, 1975 and Shaffer et. al., 1981). In addition, Shafie and Badreldin (1962) stated that thermal stress of direct solar radiation in Egypt caused a decrease in $\mathrm{Hb}$ conc. in buffaloes and cattle breeds. They postulated that these animals reduced the $\mathrm{Hb}$ content in their blood to check the metabolic rate, thus, reducing production of metabolic heat.

Responses of leukocyte cells types \% to heat stress are shown in Table 2 . The monocytes, neutrophils and Neu / Lym significantly increased, while, the other types significantly showed clear drop in their percentages. The ratio neutrophils / 
lymphocytes (Neu / Lym) was increased by heat stress. Values of neutrophils and lymphocytes are in agreement with those of Omran (1999 and 2008) and Ashour et. al. (2004) under heat stress at $40^{\circ} \mathrm{C}$ in lab.

\section{Concentration of relevant plasma organic compounds}

The results presented in Table 3 indicated that the levels of TP and Alb were significantly decreased by heat stress during the two trials, while, Glo conc. was not affected. Shafie and Badreldin (1962) found that the total protein in buffaloes exposed to direct solar radiation in Egypt was decreased by $11.9 \%$. The same trend was reported by several workers who found that, serum protein conc. usually was decrease under heat stress by about 10 \% (Kamal et. al., 1962 and 1989, AbouelNaga, 1987, El-Masry, 1987, Habeeb, 1987 and Ashour et. al., 2000).

The levels of TL, TG and TC were significantly decreased by heat stress during the two trials, however, with greater response in the second trial (Table 3). Similar results were reported in ruminants with prolonged exposure to high AT for TL (Noble et. al., 1973, O'Kelly, 1973, Daader et. al., 1989 and Kamal et. al., 1989), and TC (Shaffer et al., 1981, Abdel-Samee, 1987, Abouel-Naga, 1987, El-Masry, 1987 and Ashour et. al., 2000).

Glucose conc. was significantly reduced due to heat stress in the two trials. Shaffer et. al. (1981) identified a highly sig. effect of seasonal temperature on blood glucose levels. The level of BUN was also significantly lowered in group A than in group B during the two trials in response to HS. El-Masry (1987) reported that BUN level was decreased due to heat stress condition in Friesian cows and calves.

\section{Concentration of relevant plasma minerals}

Table 4 shows that both $\mathrm{K}$ and $\mathrm{Na}$ conc. were increased significantly by HS, ( $4-8 \%$ ) in the two trials. P conc. significantly showed greater increase by heat stress (47 and $58 \%$ ) in the two trials, meanwhile, Ca was significantly decreased $(-20 \%)$ in the two trials.

\section{Concentration of the studied hormones}

Table 5 indicates that both $\mathrm{T}_{3}$ and $\mathrm{T}_{4}$ conc. were dropped by HS, around $50 \%$ in each hormone in the two trials. The present result is in agreement with Omran (1999 and 2008) and Ashour et. al. (2004) under HS at $40^{\circ} \mathrm{C}$. The stress caused decrease in Insulin (Ins) conc. (-60 and $-57 \%$ ) and increase in glycogen (Glg) conc. $(+29$ and $+20 \%)$ in the two trials, respectively. The increasing of plasma glycogen may by due to decreases of plasma glucose (Table 3 ) and reduced feed intake under HS. El-Masry and Habeeb (1989) reported that high AT caused drop in the conc. of Ins. Thompson (1973) concluded that acclimatization and/or acclimatization to heat stress causes an increase in BT and decrease in thyroid activity. 
Table 1. Hematological picture, Ht, \%, Hb, g/dl, RBC's X106/mm3 and WBC's X103/mm3 in calf groups ( $A$ and $B$ ) under two CTC (Mean \pm SE).

\begin{tabular}{|c|c|c|c|c|}
\hline \multirow[t]{2}{*}{ Items } & \multicolumn{2}{|c|}{$1^{\text {st }}$ trial } & \multicolumn{2}{|c|}{$2^{\text {nd }}$ trial } \\
\hline & (A) $40^{\circ} \mathrm{C}$ & (B) $25^{\circ} \mathrm{C}$ & (A) $40^{\circ} \mathrm{C}$ & (B) $25^{\circ} \mathrm{C}$ \\
\hline $\mathrm{Ht}, \%$ & $28.35 \pm 0.41^{b}$ & $35.20 \pm 0.66^{a}$ & $28.80 \pm 0.85^{b}$ & $37.00 \pm 0.91^{\mathrm{a}}$ \\
\hline $\mathrm{Hb}, \mathrm{g} / \mathrm{dl}$ & $8.84 \pm 0.14^{b}$ & $13.80 \pm 0.36^{\mathrm{a}}$ & $10.00 \pm 0.21^{b}$ & $13.35 \pm 0.21^{\mathrm{a}}$ \\
\hline $\mathrm{RBC}^{\prime} \mathrm{s}, \mathrm{X10^{6 }} / \mathrm{mm}^{3}$ & $4.65 \pm 0.07^{b}$ & $7.19 \pm 0.06^{\mathrm{a}}$ & $5.00 \pm 0.16^{b}$ & $7.02 \pm 0.10^{a}$ \\
\hline WBC's, $\times 10^{3} / \mathrm{mm}^{3}$ & $3.50 \pm 0.11^{\mathrm{a}}$ & $2.11 \pm 0.06^{\mathrm{a}}$ & $3.00 \pm 0.07^{\mathrm{a}}$ & $2.12 \pm 0.08^{a}$ \\
\hline
\end{tabular}

In the same row means with different superscripts are significantly different $(P<0.05)$.

Table 2. Leukocyte cells types (\%) of the buffalo-calf groups (A and B) under two CTC (Mean \pm SE).

\begin{tabular}{|c|c|c|c|c|}
\hline \multirow[b]{2}{*}{ Types } & \multicolumn{2}{|c|}{$1^{\text {st }}$ trial } & \multicolumn{2}{|l|}{$2^{\text {nd }}$ trial } \\
\hline & (A) $40^{\circ} \mathrm{C}$ & (B) $25^{\circ} \mathrm{C}$ & (A) $40^{\circ} \mathrm{C}$ & (B) $25^{\circ} \mathrm{C}$ \\
\hline Neutrophils & $53.7 \pm 0.68^{a}$ & $47.5 \pm 0.33^{b}$ & $52.0 \pm 0.65^{\mathrm{a}}$ & $46.0 \pm 0.52^{b}$ \\
\hline Lymphocytes & $35.4 \pm 0.54^{b}$ & $42.4 \pm 0.4^{a}$ & $36.9 \pm 0.85^{b}$ & $43.4 \pm 0.78^{a}$ \\
\hline Eosinophils & $4.0 \pm 0.18^{a}$ & $5.0 \pm 0.12^{a}$ & $4.5 \pm 0.23^{a}$ & $5.13 \pm 0.23^{a}$ \\
\hline Basophils & $0.1 \pm 0.07^{\mathrm{a}}$ & $0.23 \pm 0.09^{a}$ & $0.43 \pm 0.11^{a}$ & $0.37 \pm 0.11^{a}$ \\
\hline Monocytes & $6.8 \pm 0.17^{\mathrm{a}}$ & $4.9 \pm 0.09^{b}$ & $6.2 \pm 0.21^{a}$ & $5.1 \pm 0.13^{b}$ \\
\hline Neutophils/lymphocytes & $1.52 \pm 0.20^{\mathrm{a}}$ & $1.12 \pm 0.10^{b}$ & $1.41 \pm 0.21^{\mathrm{a}}$ & $1.06 \pm 0.15^{b}$ \\
\hline
\end{tabular}

In the same row means with different superscripts are significantly different $(P<0.05)$. 
Table 3. Concentrations of the tested blood plasma organic compounds of the buffalo-calf groups ( $A$ and $B$ ) under two CTC (Mean \pm SE).

\begin{tabular}{|c|c|c|c|c|}
\hline \multirow[b]{2}{*}{ Items } & \multicolumn{2}{|c|}{$1^{\text {st }}$ trial } & \multicolumn{2}{|c|}{$2^{\text {nd }}$ trial } \\
\hline & (A) $40^{\circ} \mathrm{C}$ & (B) $25^{\circ} \mathrm{C}$ & (A) $40^{\circ} \mathrm{C}$ & (B) $25^{\circ} \mathrm{C}$ \\
\hline $\begin{array}{l}\text { Total protein } \\
(\mathrm{g} / \mathrm{dl})\end{array}$ & $8.10 \pm 0.20^{b}$ & $9.90 \pm 0.03^{a}$ & $8.30 \pm 0.09^{b}$ & $9.90 \pm 0.04^{\mathrm{a}}$ \\
\hline $\begin{array}{l}\text { Albumin } \\
\text { (g/dl) }\end{array}$ & $3.70 \pm 0.19^{b}$ & $5.50 \pm 0.10^{\mathrm{a}}$ & $3.80 \pm 0.07^{b}$ & $5.40 \pm 0.10^{\mathrm{a}}$ \\
\hline $\begin{array}{l}\text { Globulin } \\
\text { (g/dl) }\end{array}$ & $4.40 \pm 0.14^{\mathrm{a}}$ & $4.40 \pm 0.09^{a}$ & $4.60 \pm 0.09^{a}$ & $4.40 \pm 0.08^{a}$ \\
\hline $\begin{array}{l}\text { Total lipid } \\
\text { (mg/dl) }\end{array}$ & $227.00 \pm 12.10^{c}$ & $670.00 \pm 33.30^{b}$ & $210.00 \pm 10.10^{c}$ & $770.00 \pm 16.10^{a}$ \\
\hline $\begin{array}{l}\text { Triglycerides } \\
\text { (mg/dl) }\end{array}$ & $64.52 \pm 1.70^{c}$ & $146.60 \pm 9.40^{b}$ & $70.30 \pm 1.40^{\mathrm{c}}$ & $185.20 \pm 3.60^{a}$ \\
\hline $\begin{array}{l}\text { Total cholesterol } \\
(\mathrm{mg} / \mathrm{dl})\end{array}$ & $43.70 \pm 2.96^{c}$ & $86.39 \pm 3.90^{b}$ & $36.80 \pm 1.70^{c}$ & $103.40 \pm 4.30^{a}$ \\
\hline $\begin{array}{l}\text { Glucose } \\
\text { (mg/dl) }\end{array}$ & $47.01 \pm 3.40^{b}$ & $78.80 \pm 1.50^{a}$ & $40.00 \pm 2.10^{b}$ & $75.00 \pm 2.50^{\mathrm{a}}$ \\
\hline $\begin{array}{l}\text { Urea } \\
(\mathrm{mg} / \mathrm{dl})\end{array}$ & $31.61 \pm 1.21^{b}$ & $47.71 \pm 0.49^{a}$ & $28.90 \pm 0.79^{c}$ & $48.50 \pm 0.30^{a}$ \\
\hline
\end{tabular}

In the same row means with different superscripts are significantly different $(P<0.05)$.

Table 4. Concentrations of tested blood plasma minerals of the buffalo-calf groups (A and B) under two CTC (Mean \pm SE).

\begin{tabular}{|c|c|c|c|c|}
\hline \multirow[b]{2}{*}{ Items } & \multicolumn{2}{|c|}{$\mathbf{1}^{\text {st }}$ trial } & \multicolumn{2}{|c|}{$2^{\text {nd }}$ trial } \\
\hline & (A) $40^{\circ} \mathrm{C}$ & (B) $25^{\circ} \mathrm{C}$ & (A) $40^{\circ} \mathrm{C}$ & (B) $25^{\circ} \mathrm{C}$ \\
\hline $\begin{array}{l}\text { Sodium } \\
(\mathrm{mg} / \mathrm{dl})\end{array}$ & $358.98 \pm 8.00^{a}$ & $333.55 \pm 4.40^{b c}$ & $344.08 \pm 8.50^{b}$ & $329.60 \pm 7.20^{c}$ \\
\hline $\begin{array}{l}\text { Potassium } \\
(\mathrm{mg} / \mathrm{dl})\end{array}$ & $20.67 \pm 0.20^{\mathrm{a}}$ & $19.11 \pm 0.20^{b}$ & $20.67 \pm 0.30^{\mathrm{a}}$ & $19.11 \pm 0.30^{b}$ \\
\hline $\begin{array}{l}\text { Calcium } \\
\text { (mg/dl) }\end{array}$ & $10.20 \pm 0.34^{c}$ & $12.80 \pm 0.20^{\mathrm{a}}$ & $9.10 \pm 0.16^{d}$ & $11.40 \pm 0.14^{b}$ \\
\hline $\begin{array}{l}\text { Phosphorus } \\
\text { (mg/dl) }\end{array}$ & $7.20 \pm 0.05^{a}$ & $4.90 \pm 0.20^{b}$ & $7.10 \pm 0.07^{\mathrm{a}}$ & $4.50 \pm 0.30^{b}$ \\
\hline
\end{tabular}

In the same row means with different superscripts are significantly different $(P<0.05)$. 
Table 5. Concentrations of the studied hormones of the buffalo-calf groups (A and B) under two CTC (Mean \pm SE).

\begin{tabular}{|c|c|c|c|c|}
\hline \multirow[b]{2}{*}{ Hormone } & \multicolumn{2}{|c|}{$1^{\text {st }}$ trial } & \multicolumn{2}{|c|}{$2^{\text {nd }}$ trial } \\
\hline & (A) $40^{\circ} \mathrm{C}$ & (B) $25^{\circ} \mathrm{C}$ & (A) $40^{\circ} \mathrm{C}$ & (B) $25^{\circ} \mathrm{C}$ \\
\hline $\begin{array}{l}\text { Triiodothyronine } \\
\text { (ng/dl) }\end{array}$ & $114.73 \pm 5.02^{b}$ & $233.64 \pm 15.77^{\mathrm{a}}$ & $121.43 \pm 2.24^{b}$ & $228.01 \pm 14.08^{a}$ \\
\hline $\begin{array}{l}\text { Thyroxine } \\
(\mu \mathrm{g} / \mathrm{dl})\end{array}$ & $2.59 \pm 0.20^{\mathrm{c}}$ & $6.03 \pm 0.16^{\mathrm{a}}$ & $2.49 \pm 0.10^{c}$ & $5.38 \pm 0.24^{b}$ \\
\hline $\begin{array}{l}\text { Insulin } \\
(\mu \mathrm{lU} / \mathrm{ml})\end{array}$ & $19.37 \pm 1.17^{b}$ & $48.30 \pm 2.25^{\mathrm{a}}$ & $20.39 \pm 0.74^{b}$ & $47.08 \pm 2.16^{\mathrm{a}}$ \\
\hline $\begin{array}{l}\text { Glycogen } \\
(\mathrm{pg} / \mathrm{ml})\end{array}$ & $86.44 \pm 3.06^{a}$ & $56.82 \pm 2.17^{b}$ & $80.57 \pm 9.14^{a}$ & $67.42 \pm 8.44^{b}$ \\
\hline
\end{tabular}

In the same row means with different superscripts are significantly different $(P<0.05)$. 


\section{CONCLUSION}

The blood picture for buffalo-calves showed clear drop in $\mathrm{Ht}, \mathrm{Hb}$ conc. and RBCs count. This decrease may be, in part, due to hemodilution by excess of WI. However, the drop in $\mathrm{Hb}$ and RBCs was more than the decrease in $\mathrm{Ht}$ which indicated other mechanism imposing drop in $\mathrm{Hb}$ and $\mathrm{RBCs}$ to reduce oxidation activity of metabolism, thus, subsequent drop in metabolic heat production. On the contrary, the WBCs count was increased as indication of immunological activity. This immunological reaction was fortified by increase in Neu \% against decreases in Lym $\%$ leading to increase in the ratio $\mathrm{Neu} / \mathrm{Lym}$.

The response of the studied blood plasma metabolites to heat stress showed great decrease in TL, TC and TG followed by Glu . These reductions indicated hamper of metabolic activities subsequently less product of metabolic heat. The drop in TP suggests effect of hemodilution along with drop in buildup of plasma proteins. The increase in Glb against drop in Alb indicates control in colloid osmotic pressure to maintain proper blood circulation.

Heat stress caused increasing in conc. of $\mathrm{k}, \mathrm{Na}$ around $10 \%$ opposite to 20 \% decrease in $\mathrm{Ca}$, in both trials. The $\mathrm{P}$ showed more than $50 \%$ increase in both trials of stress. This increasing should be, particularly, due to hemoconcentration by activated water vaporization from the animals surface and increased respiratory vaporization. Nevertheless, the difference in the rate of increase between $\mathrm{K}, \mathrm{Na}$ and $\mathrm{P}$ indicated active physiological arrangements concomitant with the hemoconcentration. The opposite trend by reduction in $\mathrm{Ca}$, equal in the two treatments, emphasizes effective physiological interference.

Heat stress caused reduction in insulin (Ins) conc. (-60 and -57 in the two trials), coincidentally, the glycogen (Glg) conc. increased ( +29 and +20 in the two trials). This opposite trend in the conc. of these hormones indicates hormonal control on critical drop in Glu conc. in blood plasma under HS, (47 and $40 \mathrm{mg} / \mathrm{dl}$ ) in comparison to (79 and $75 \mathrm{mg} / \mathrm{dl}$ ) under CS.

It is clear that T3 and T4 hormone conc. were decreased more than $50 \%$ in response to HS, almost with equal levels in both trials, devoting depression in general metabolic activity, thus, metabolic heat production. 


\section{REFERENCES}

1. Abdel-Samee, A. M. 1987. The role of cortisol in improving productivity of heat streesed farm animals with different techniques. Thesis Ph. D., Fac. Agric., Zagazig, University.

2. Abouel-Naga A. L. 1987. The role of aldosterone in improving productivity of heat stressed farm animals with different techniques. Thesis Ph. D., Fac. Agric., Zagazig University.

3. Ashour, G., L. R. Hassan, F. I. Omran and M. M. Shafie. 2004. Thermorespiratory responses hematological and hormonal reactions of buffalo and Friesian calves to the rise in environmental temperature. Egyptian J. Anim. Prod., 41 Suppl. Issue, Nov., 353.

4. Ashour, G., L. R. Hassan, F. I. Omran and M. M. Shafie. 2000. Growth performance of buffalo and Friesian calves under natural climatic and steady heat stress conditions. J. Agric. Sci. Mansoura Univ., 25, 2503.

5. Bond, J., J. B. Powell, D. J. Undersander, P. M. More, H. F. Tyrrel and R. R. Ottjen. 1984. Forage composition and growth and physiological characteristics of cattle grazing several varieties of tall fescues during summer conditions. J. Anim. Sci., 59, 584.

6. Daader, A. H., I. F. M. Marai, A. A. Habeeb and H. M. Yousef. 1989. Improvement of growth performance of Friesian calves under Egyptian subtropical conditions. 1- Internal cooling technique using diuretics and drinking cool water. Proceedings 3rd Egyptian British Conf. Ani., Fish and Poul. Prod., Vol. 2, Alexandria, Egypt, 595.

7. El-Masry, K. A. 1987. The role of thyroxine in improving productivity of heat stressed farm animals with different techniques. Thesis Ph.D., Fac. Agric., Zagazig University.

8. El-Masry, K. A. and A. A. Habeeb. 1989. Thyroid function in lactating Friesian cows and water buffalo and its relationship with their milk yield in winter and summer Egyptian conditions. Proc. 3rd Egyptian - British Conf. on Animal, Fish and Poultry Prod., 7-10 October, 1989 , Alex. Univ.

9. Habeeb, A. A. 1987. The role of insulin in improving productivity of heat stressed farm animals with different techniques. Thesis, Ph.D., Fac. Agric., Zagazig University.

10. Kamal, T. H., K. A. El-Masry and A. M. Abdel-Samee. 1989. Influence of hot climate and spray cooling on daily body gain and thyroxine and cortisol levels of Friesian calves. Proc. Inter. Symp., 5-7 Nov., 1988, Cairo, EAAP Publication No. 38, 180. 
11. Kamal, T. H., H. D. Johnson and A. C. Ragsdale. 1962. Metabolic reactions during thermal stress ( $35^{\circ}$ to $95^{\circ} \mathrm{F}$ ) in dairy animals acclimated at $50^{\circ}$ and $80^{\circ} \mathrm{F}$. Mo. Agric. Exp. Sta. Res. Bul., 785.

12. Noble, R. C., T. C. O'kelly and J. H. Moore. 1973. The effects of exposure to warm environmental on bovine plasma lipid composition. Lipids 8, 216.

13. O'Kelly, T. C. 1973. Seasonal variations in the plasma lipids of genetically different types of cattle stress on different diets. Comp. Bioch. and Physiol., 44 A, 303.

14. Omran Fayza, I. 1999. Physiological reaction and growth performance of buffaloes and Friesian calves to heat stress. Thesis M. Sc., Fac. Agric., Cairo University.

15. Omran Fayza, I. 2008. Impact of thermo-physiological reaction on growth performance of buffalo calves. Thesis Ph. D., Fac. Agric., Cairo University.

16. Rowlands, G. J., W. Little, R. R. Manston and M. D. Sally. 1974. The effect of season on the composition of the blood of lactating and non-lactating cows as revealed from repeated metabolic profile tests on 24 dairy herds. J. Agric. Sci., 83, 27.

17. SAS 2000. Statistical Analysis System Institute, Inc., Cary, Nc., USA.

18. Shaffer, D., J. D. Roussel and K. L. Koonce. 1981. Effects of age, temperature season and breed on blood characteristics of dairy cattle. J. Dairy Sci., 64, 62.

19. Shafie, M. M. 1958. Heat regulating mechanism in buffaloes and cattle as affected by haematological values and circulation in skin. Thesis Ph. D., Fac. Agric., Cairo University.

20. Shafie, M. M. 1985. Physiological responses and adaptation of water buffalo. In Stress Physiology In Livestock, Vol. 11, M. K. Yosuef (Ed.) Ungulates, CRC, Florida, USA, 67.

21. Shafie, M. M. 1993a. Biological adaptation of buffaloes to climatic conditions. As for Ashour, 1993., 176.

22. Shafie, M. M. 1993b. Environmental effects on water buffalo production. World Anim. Rev., FAO, 77, 21.

23. Shafie, M. M. and A. L. Badreldin. 1962. The role of blood in regulating body heat in bovines. Egyptian J. Anim. Prod., 2, 62.

24. Shebaita, M. K. and T. H. Kamal. 1975. Lean body mass and body fatty change in lactating animals under Sahara climate. World Rev. Anim. Prod., $11,50$.

25. Thompson, G. E. 1973. Review of the progress of dairy science climatic physiology of cattle. J. Dairy Sci., 40, 441. 


\section{استجابة هيماتولوجلي الدم ومكوناته و المعادن والهرمونات للإجهاد الحراري في

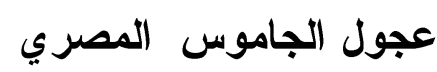

فايزة إبر اهيم عمران 1 ، جمال عاشور2 ، محمد محمد يوسف1 ، محمد محمود الشافعي2

$$
1 \text { كلبة الزراعة - معوث الإنتاج الحبواني - مركز البحوث الزراعية - وزارة الزراعة - الدقي - جبزة }
$$

أجريت هذه الدر اسة بالمزرعة التجريبية بمعل فسيولوجيا الحيوان - كلية الزراعة جامعة القاهرة بالجيزة خلال موسم صيف عام 2004. و كان الهدف من هذه الدراسة هو تقدير الإستجابة

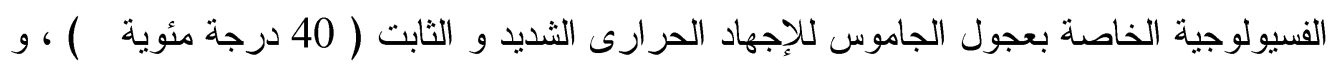

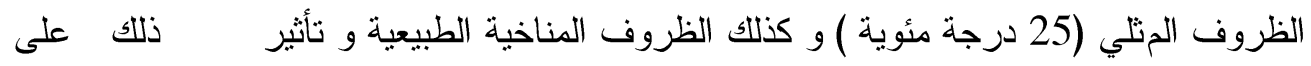
هيماتولوجي الدم ومكوناته.

و أستخدم فى هذة الدر اسة ثمانية عجول جاموسى (4 في كل معمل) عمر كل منها ستة سنة

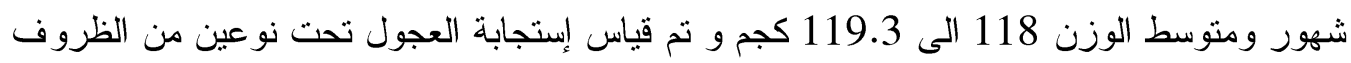
الحرارية هما الإجهاد الحر ارى داخل معمل (أ) حيث كانت درجة الحرارة ثابتة و مستمرة (

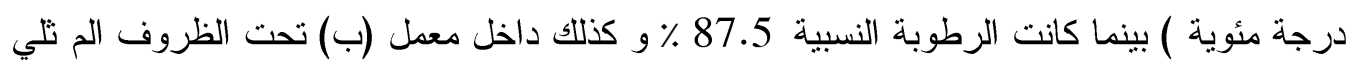
لفترة درجة الحرارة (25 درجة مئوية) و الرطوبة النسبية (65.5 ٪) و أجريت تجربئن كل منهما

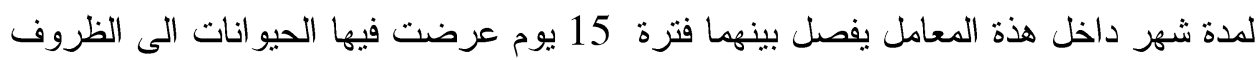
المناخية الطبيعية خارج المعمل.

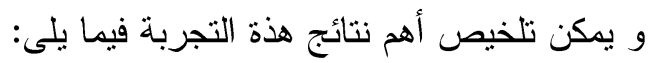

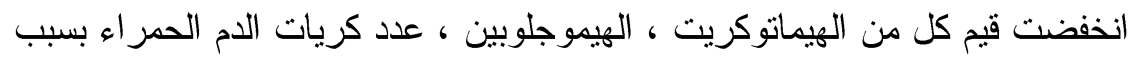

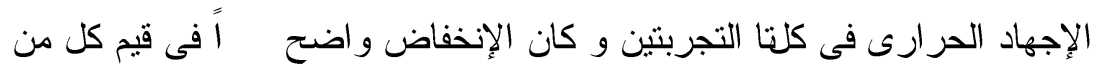

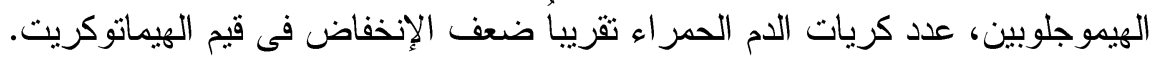

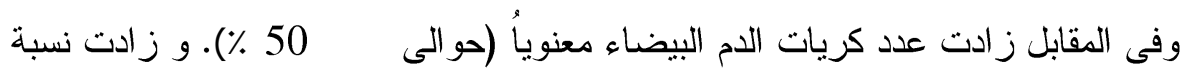

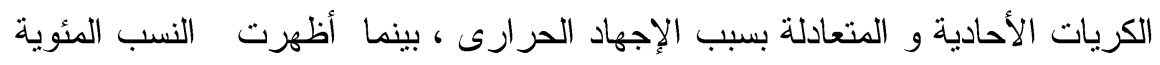

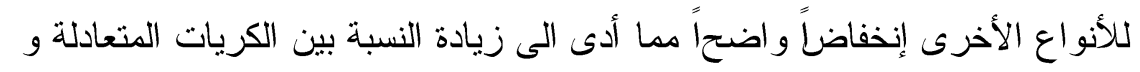

$$
\text { الليمفاوية. }
$$

ادي الاجهاد الحراري الي انخفاض مستويات كل من الدهون الكلية،والكوليستيرول الكلي

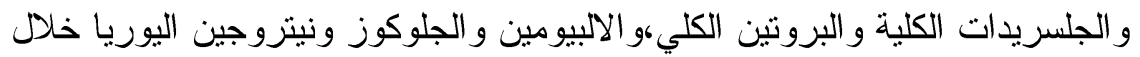

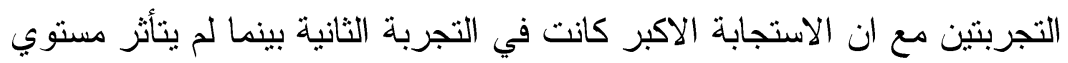


• في كلتا التجربتين ادي الاجهاد الحراري الي زيادة طفيفة (4-8 ٪) في تركيز كل من

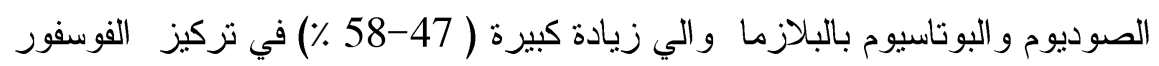

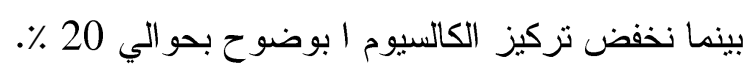

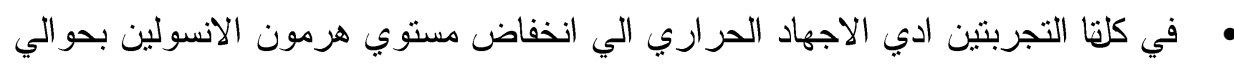

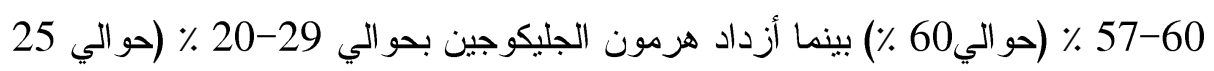

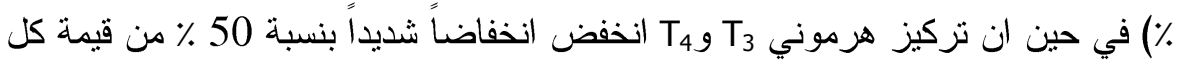
منهما.

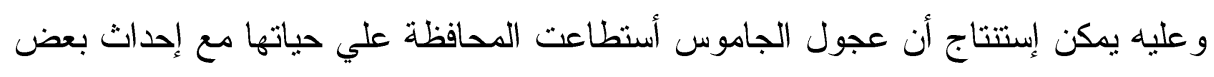
التغير ات الكيميائية والفيزيائية التي أدت إلي تأخير في النمو وذلك عند تعرضها للحرارة

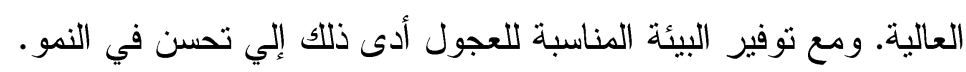

